\title{
The Relationship of Investor's Demographic Traits and Personality Type with Financial Risk Tolerance in Investment Decisions.
}

\author{
Muhammad Nauman Sadiq ${ }^{1}$, Muhammad Akhtar ${ }^{2}$
}

\begin{abstract}
With an assorted sample of customers from various banks of Pakistan, the authors tried to establish relationship of investor's demographic traits and personality type with financial risk tolerance during the choice of investment. Results provide sustenance for the projected hypotheses such as investor's age, income, financial knowledge, family size, occupation and academic qualification has association with financial risk tolerance capability.Investors doing service in an organization tolerate more risk as compare to the investor having their own business. However, Investors marital status and gender has no effect on financial risk tolerance. Investor either married or unmarried showed similar attitude toward financial risk tolerance. Empirical results also provide evidence that investors having type A personality are more financial risk taker as compare to type B personality.
\end{abstract}

Keywords: demographic traits; financial risk preferences; investment decisions; personality type.

JEL-Classification: J11, G32. G11, L84, D14

\section{Introduction}

Traditional financial paradigm elucidates that markets are efficient, and investors are rational. These studies presume that "investors are rational", when investors receive new information, they rationally deliberate the all available information and select their portfolio between alternatives. (Fama, 1965, 1970). Besides this traditional financial paradigm, several studies revealed investors are not rational, they make decisions under the influence of several personal, social, and economic factors, and irrationality is also shown by investors during financial decision-making process (Barberis \& Thaler, 2003). To explain the behavioural aspects during decision making process now a day a new paradigm of finance named behavioural finance is used to understand the

${ }^{1}$ Govt Post Graduate (boy's) college Bagh A.K

${ }^{2}$ FAST School of Management, National University of Computer \& Emerging Sciences (FAST NUCES), Islamabad *Corresponding author:nauman_sns22@yahoo.com,

OPENSS This work is Licensed under a Creative Commons Attribution-Noncommercial 4.0 International License (i) ()


behavioural aspects of investors while making the financial decision. This approach combined the psychology and economics to explain the reason for each irrational decision of investors during portfolio selection (Belsky \&Gilovich, 1999). In behavioural finance literature two schools of thought exist which explained the factors influencing the investors behaviour. One school of thought shown investors perception of risk and their investing behavior is influence by their demographic characteristics (Bajtelsmit \& Bernasek, 1996; Barber \& Odean, 2001). Other school of thought revealed investor's behaviour is influence by their psychological characteristics (Costa $\&$ McCrae, 1992). Psychological factors which influence the rationality of the investors are overconfidence, representativeness, mental accounting, disposition effect and conservatism (Ritter, 2003).

Numerous studies find distinct factors that influenced the financial decision-making process. Study finds out that investors personality and demographic profile are two determinants to know investors behaviour toward wealth management (Verma, 2008; Kannadhassan, 2015). During financial decisions, investors select different risk preferences according to their psychological traits (Barberis \& Thaler, 2003). Research conducted on the investors of Rajasthan explored that investors having different demographic traits shown dissimilar attitudes, People select their risk level according to their demographic profile (Jain \& Mandot, 2012; Geetha \& Vimala ,2014; Khan, 2017). Further some studies revealed that investors personality type also has relation with investors risk tolerance level during financial decisions (Mahmood, 2015). Study concluded that investors with type A personality traits tolerate more risk as compare to the investors having type B personality traits (Thanki, 2015; Kubilay \& Ali ,2016). From all these studies, this is extracted that investors make decisions under the influence of numerous factors. Investors make dissimilar choices of benefit when they face uncertain conditions (Talangy, 2004). Investors risk tolerance attitude is not a static phenomenon; investors risk tolerance attitude change with the change of their economic, social, and demographic factors (Grable et al.2006). This study has discussed the two important and vital factors i.e. demographic characteristics and investors personality type in relation with financial risk tolerance with the perspective of Pakistan. The study established that Investors doing service in an organization tolerate more risk as compare to the investor having their own business. However, Investors marital status and gender has no effect on financial risk tolerance. Investor either married or unmarried showed similar attitude toward financial risk tolerance. Empirical results also provide evidence that investors having type A personality are more financial risk taker as compare to type B personality. Further investor's age, income, financial knowledge, family size, occupation and academic qualification has association with financial risk tolerance capability. This study has significance for the financial planners, individual investors, financial advisors, and managers to understand the investor's behaviour regarding financial risk tolerance during investment decisions.

Sukkur IBA Journal of Management and Business - SIJMB | Volume 6 No. 1 January - June 2019 @ Sukkur IBA University 


\section{Theory and Hypotheses}

\subsection{Demographic Characteristic}

Demographics are the qualitative characteristics of the population, which can be, quantify. Commonly used demographics include age, gender, marital status, income level, Education, investment knowledge and Occupation. Several studies are accompanied to examine the relationship between investor's demographics and their financial risk tolerance attitude. Investment choice of the investors is associated with its demographic profile (Mehta \&Aggarwal, 2011; Jain \& Mandot, 2012).

\subsection{Gender}

While discussing investors demographic characteristics gender is consider as the first categorizing and discriminating factor (Bernasek et al. 1996). Emotional variability between male and female caused the different financial risk tolerance attitude (Loewenstein et al.2001). Due to emotional variability, female investors shown broader risk aversion as compare to male investors (Stendardi et al. 2002). In our culture, widespread belief is existing that men are greater risk taker than women (Slovic, 1996; Khan, 2017). Research disclosed that while comparing with male female shown more risk aversion not only in financial decision making but also in other actions like seat belt usage and smoking (Hersch, 1996). Another research conducted in Bhopal (India) disclosed that male investors shown aggression while making the financial decisions and female investors shown conservative behaviour, that's why female investors are avoiding to invest in bond and shares due to high financial risk (Rajdev, 2013).Several studies revealed that no significant association is exist between investors gender and their ability of financial risk tolerance (Schubert et al. 1999: 384-385).Therefore, on the basis of above arguments the following hypothesis has been formulated:

Hypothesis (1): Investor's gender has relationship with their level of financial risk tolerance.

\subsection{Age}

Investor's financial risk tolerance attitude is also based on their age. This association was originally observed by (Wallach \& Kogan, 1961). By using the choice dilemmas their first experimental research shown young individuals, tolerate more risk as compare to older individuals. These findings later open a door for similar research. Several studies shown the result, which supports the results of (Wallach \& Kogan, 1961) and concluded that inverse relationship is exist between investors age and their ability of financial risk tolerance (Jiankopolos \& Bernasek 2006; Khan, 2017). Old investors do not have enough income to bear the loss and they save their money after the period of retirement (Arora \&Kumari, 2015). Several studies also shown contradictory results and shown investors ability of risk tolerance increase with the passage of time (Wang \&Hanna, 1997). Young investors tolerate less financial risk as compare to older investors (Grable \& Lytton, 1999b). Old investors make healthier financial decisions

Sukkur IBA Journal of Management and Business - SIJMB | Volume 6 No. 1 January - June 2019 @ Sukkur IBA University 
because of their financial knowledge and financial experience (Korniotis \& Kumar 2011; Frijns, Koellen \& Lehnert, 2008). Along these studies, some studies shown no significant association is exist between investors age and their financial risk tolerance ability (Anbar \& Eker 2010; Gumede, 2009; Al-Ajmi, 2008). Therefore, on the bases of above arguments the following hypothesis has been formulated:

Hypothesis (2): Investor's age has relationship with their level of financial risk tolerance.

\subsection{Education}

Third demographic factor which is contemplate as a financial decision persuading factor is the formal academic education (Sung \& Hanna, 1996). Generally, it is perceived by many researchers and financial planner that investors having upper level of education tends to invest in higher risky stocks and investor having no or low formal education tends to invest in less risky areas of investment (Thanki, 2015). Study explored that education is a vital factor to overpowering the obstacles to stockholder that is including the loss related with the equities. Further they explored that investors having no formal school education are less likely to hold stock as compare to investor having some formal education (Haliassos \& Bertaut, 1995; Masters, 1989). Increase in formal education caused an increase in the ability of financial risk tolerance (Graham et al. 2009: Kimball et al 2007). Increasing education initiate an increase in the aptitude of investors to take higher financial risk (Racciardi .2007; Khan, 2017).

Along these outcomes, numerous studies revealed the opposing results. Study disclosed that tendency to tolerate financial risk decrease with an increase in the level of formal education, because investor having higher education considered the all relevant factors while making the investment choice (Mittal and Vyas, 2007). Along these results, several studies shown no significant association is exist between investors qualification and financial risk tolerance (Strydom et al 2009; Gumede, 2009: 27). Therefore, on the bases of above arguments the following hypothesis has been formulated:

Hypothesis (3): Investor's qualification has relationship with their level of financial risk tolerance.

\subsection{Marital Status}

Marital status is also used by the investment managers as a factor affecting the risk tolerance aptitude of investors. The intention behind this factor is that sole person has less to lose by accepting superior risk as compare to married individual who have tasks for themselves and for their family. (Lazzarone, 1996, Barber \& Odean, 2001: Roszkowski et al. 1993). Study revealed wedded male and female shown dissimilar risk tolerance attitude. Married female shown less risk tolerance attitude while single women and married men shown moderate risk tolerance attitude. Further, this study shown single man tolerates more risk (Hinz et al, 1997). These results are also supported

Sukkur IBA Journal of Management and Business - SIJMB | Volume 6 No. 1 January - June 2019 @ Sukkur IBA University 
by the study conducted in Rajasthan (India). Study shown unmarried investors tends to invest in more risky assets while married investors preferred the less risky investments (jain \& Mandot 2014). Therefore, on the bases of above arguments the following hypothesis has been formulated:

Hypothesis (4): Investor's marital status has relationship with their levels of financial risk tolerance.

\subsection{Income Level}

Along others demographic factors investors income level is also considered as a factor affecting their attitude toward financial risk tolerance. Study revealed investor investment pattern is depends upon their income group. These groups are categories into higher, middle, and lower group of incomes. Investors from these different groups shown different investment and saving pattern. Further this study determined that investors having annual income less than one hundred thousand belongs to lower group, while investors having income from one hundred thousand to two hundred and fifty thousand belongs to middle group of incomes, while investors having income above from two hundred and fifty thousand belongs to higher group of incomes (Mittal \& Vyas, 2007). While studying the investors level of income and their investment pattern this study shown that investors belongs to lower group of incomes tend to invest in lower risky areas of investment such as post office or bank deposits. While investors belong to middle group of incomes invest in moderate risky areas of investment such as mutual funds etc., while investors belong to higher group of incomes tends to invest in higher risky areas of investment such as equities, Stock, and real estate etc. (Verma,2008; Mittal \& Vyas, 2007). Higher level of income caused greater ability of financial risk tolerance. (Parker \& Terry 2002; MacCrimmon \& Wehrung, 1986). Higher level of income tends the investors to select more volatile portfolio (Barber\& Odean, 2001; Bernheim et al. 2001). Along these results, several studies shown no significant association is exist between these variables (Strydomet al, 2009). Therefore, on the bases of above arguments the following hypothesis has been formulated:

Hypothesis (5): Investor's income level has relationship with their level of financial risk tolerance.

\subsection{Occupation}

Occupational status is also considering as a factor affecting the investors ability of financial risk tolerance. People having their own businesses, profession and trade takes more financial risk as compare to people who work for other against fixed salary (MacCrimmon \&Wehrung, 1985). Investors with higher ranked occupations tolerate more financial risk as compare to investors having low ranked professions (Roszkowski et al. 1993; Barnewall, 1988; Sireesha \& Laxmi, 2013). Another study also divulged that investors occupation has a relationship with financial risk level occupied by her /

Sukkur IBA Journal of Management and Business - SIJMB | Volume 6 No. 1 January - June 2019 @ Sukkur IBA University 
him. (Jain, \&Mandot, 2012). Another study revealed both salaried individual and self employed shown high risk aversion and private salaried individual shown high-risk appetite (Chattopadhyay \& Dasgupta, 2015). Therefore, on the bases of above arguments the following hypothesis has been formulated:

Hypothesis (6): Investor's occupation has relationship with their levels of financial risk tolerance.

\subsection{Family Size}

Family size of investors is also deliberated as a factor influences on their financial risk taking behaviour. Generally, it is perceived that investors having fewer dependents are tend to take more risk as compare to the investors having more dependents. Study shown households having young children avoid risky assets. On the other side, investors having kids of 6 to 11 years and adolescent tends to take more risky assets (Xiao, 1996). Increase in family size and number of dependents caused a decreased in the ability of risk tolerance (Lease, Lewellen\& Schlarbaum, 1977). Another study also finds that large number of dependents lesser risk tolerance aptitude and upsurge risk aversion (Chaulk et al. 2003). Another Study also support these results and concluded that as the number of dependents of a respondent upsurge it lessens their aptitude of risk tolerance (Sulaimon, 2012). Therefore, on the bases of above arguments the following hypothesis has been formulated:

Hypothesis (7): Investor's family size has relationship with their levels of financial risk tolerance.

\subsection{Financial Knowledge}

Financial knowledge is also important for the investors to select the area of investment according to their ability of risk tolerance. Investor having lower financial knowledge mostly depends on instruction of friends and family, while investors having high investment knowledge gain high returns (Tamimi \& Kalli, 2009; Shaikh\& Kalkundarikar, 2011). Similar study divulged that investment knowledge and investment ability tends the investors to select the hotter stock (Tourani-Rad \& Kirkby, 2005). Another study uncovered that investment knowledge upsurge the risk tolerance ability of investors. Educated investors desire more risk for higher return as compare to uneducated. (Grable, 2000; Hifza et al. 2011). Study revealed that an increase of 0.104 points is occur in investor level of risk tolerance with an increase of one point in knowledge (Jain, \&Mandot, 2012). Therefore, on the bases of above arguments the following hypothesis has been formulated:

Hypothesis (8): Investor's financial knowledge has relationship with their level of financial risk tolerance.

Sukkur IBA Journal of Management and Business - SIJMB | Volume 6 No. 1 January - June 2019 @ Sukkur IBA University 


\subsection{Personality Type}

Personality can be defined as "The way an individual interacts, reacts and behaves with others and is often exhibited through measurable traits" (Young et al. 2012; Kourtidis et al. 2011). Because of the development of personal memories, attitudes, values, skills, habits and social relationship, individuals shown different personality traits (Mischel \& Shoda, 2004). Among other behavioural influencing factors, investors personality is also used as behavioural influencing factor. Studies shown some aspects of investors decisions are explained by their personality (Filbeck, Hatfield, \& Horvath, 2005). Investors having type A personality tends to tolerate more financial risk as comparing to individual having type B personality. Individual having type A personality are more risk seeker because these types of individual have higher level of income, adequate financial and academic knowledge and have higher occupational status (Carducci \& Wong, 1998). Study concluded that investors with Type A personality tolerate more risk as comparing to the investors having type B personality trait (Thanki, H 2015). Therefore, on the bases of above arguments the following hypothesis has been formulated:

Hypothesis (9): Investor's personality type has relationship with their level of financial risk tolerance.

\section{Method}

\subsection{Sample and Data Collection Procedures}

Present study has interacted the individuals involved in investment with banks in saving accounts, mutual funds, and bank assurance. According to (Taylor et al. 2006) questionnaires are an influential and sensible method to capture the attitude and opinions of the large number of target people. Present quantitative study used structured questionnaire to collect data. Present study used investors personality and their demographic traits as independent variable while financial "Risk" as a dependent variable. Using convenience sampling method present study interacted the 250 bank customers located in Rawalpindi and Islamabad. Out of which we received the responses from 230. Among these questionnaires 10 were finded incomplete, so finally study used 220 responses as a sample.

\section{Measures}

\subsection{Measurement of Financial Risk Tolerance Level}

To quantify the financial risk tolerance level of an investors study used the "risk assessment questionnaire" developed by (Grable \& Lytton, 1999). This assessment questionnaire encompasses 13 multiple-choice questions. Values between 1 to 4 are assigned to each question according to the risk level involved in each. These questions cumulatively showed the scores between thirteen to forty-seven. Scores between 0 to 18 shown the low level of risk tolerance. Scores between 19 to 22 shown the below average level of risk tolerance. Scores between 23 to 28 showed the moderate level of

Sukkur IBA Journal of Management and Business - SIJMB | Volume 6 No. 1 January - June 2019 @ Sukkur IBA University 
risk tolerance. Scores between 29 to 32 presented the above average level of risk tolerance and scores between 33 to 47 shown the high level of risk tolerance. These categories also used by (Khakhdia, 2014) for similar study in Ahmadabad city India.

\subsection{Measurement of Demographic Factors}

Investor's demographic characteristics included gender, age, income level, marital status, financial knowledge, formal school education, occupation, and family size. Investor gender is a "categorical variable which can be dummy coded i.e. 1=male, $2=$ female to use it as an interval level variable" (Grable, 1997). Age is a continuous variable, which was categories into different groups, each group shown the age of investors. Further study used the income slabs, through which investors could select their income level on an annual basis. Marital status was also used as an independent variable. Wherein marital status was subcategories as unmarried, married, divorced, and widow. Besides these, investors were also asked to tell us about their financial knowledge, Option were given to investors to select their financial knowledge either they have little knowledge, moderate knowledge, good knowledge, or very good knowledge. Formal school education of investors was also used as independent variable, and investors were asked to select their education level either they are nongraduate, graduate or have post graduate qualification or have any professional education. Investor's occupational status was also used as independent variable. Investors were categories into different occupation status including service, professional, student and other. Last demographic factor, which was used in this study, is the family size of the investors. Investors having different family size are categories into different groups.

\subsection{Measurement of Personality Types}

To find out the personality type of the investors this study used the questionnaire developed by (Howard \&Glazer, 1985). Questionnaire contains 20 questions and each question contains 1 to 7 scores. These questions cumulatively shown the scores between 20 to 140 . Scores between 20 to 80 shown that investors have type B personality type while scores between 81 to 140 shown investors have type A personality type. Type A personality represent those investors having more ability of financial risk tolerance. While investors with type B personality are risk averse (Wong \& Carducci, 1991) Most of previous studies also used this category to rank the investors personality type (Carducci \& Wong ,1998; Thoresen \& Low ,1990).

\section{Data Analysis}

Present study used the nominal and ordinal variable; therefore, chi square test was used to find the relationship of investors demographic factors and personality types with their level of financial risk tolerance. These statistical methods are also used by (Jain \& Mandot 2012; Khakhdia 2014). Statistical package SPSS is used to run the test and analyze the data.

Sukkur IBA Journal of Management and Business - SIJMB | Volume 6 No. 1 January - June 2019 @ Sukkur IBA University 


\subsection{Results}

\subsubsection{Reliability test for questionnaire measuring the financial risk level}

The first step in the data analysis was the reliability checking of instrument. Studies shown that risk assessment questionnaire must produce the reliability coefficient ranging from 0.5 to 0.80 to show the consistency (Pedhazur, 1982). Present instrument shown the Cronbach's coefficient alpha 0.84 which shown the reliability of the instrument.

Table 1: Reliability Statistics of Questionnaire Measuring the Financial Risk Level

\begin{tabular}{ll}
\hline Cronbach's Alpha & No. of Items \\
\hline 0.844 & 13 \\
\hline
\end{tabular}

Table 2: Relationship of Investors Gender and their Financial Risk Tolerance Levels

\begin{tabular}{llllllll}
\hline & & Risk & & & \multicolumn{2}{c}{ Total } \\
\cline { 3 - 6 } & & Low & $\begin{array}{l}\text { Below } \\
\text { average }\end{array}$ & Average & $\begin{array}{l}\text { Above } \\
\text { average }\end{array}$ & High & \\
\hline Gender & Male & 24 & 14 & 57 & 31 & 21 & 147 \\
Total & Female & 20 & 8 & 26 & 12 & 7 & 73 \\
\hline
\end{tabular}

Table 2 revealed that investors with different gender shown the similar risk tolerance level while making the financial decisions.

Table 3: Chi-square Test for Investors Gender and Financial Risk Tolerance

\begin{tabular}{llll}
\hline & Value & DF & Asymp. Sig. (2-sided) \\
\hline $\begin{array}{l}\text { Pearson Chi- } \\
\text { Square }\end{array}$ & $4.604^{\mathrm{a}}$ & 4 & 0.330 \\
\hline
\end{tabular}

Table 3 revealed the Pearson chi-square test results for investors gender and their financial risk tolerance and indicated calculated value that is 4.604 with significance value of .330. Where tabulated value of chi-square using 5\% level of significance at 4 degree of freedom is 9. 488. As our calculated value is less than the tabulated value, so we accept our null hypothesis and finds, investors gender has no significance relationship with their levels of financial risk tolerance. Investors either they are male or female, shown the similar risk tolerance level.

Table 4 revealed that investors with diverse income level shown the dissimilar trend while making the financial decision-making process. Investors with low level of

Sukkur IBA Journal of Management and Business - SIJMB | Volume 6 No. 1 January - June 2019 @ Sukkur IBA University 
income tolerate the low risk, while investors with higher level of income tolerate high risk.

Table 4: Relationship of Investors Income Level and their Financial Risk Tolerance Levels

\begin{tabular}{|c|c|c|c|c|c|c|c|}
\hline & & \multicolumn{5}{|c|}{ Risk } & \multirow[t]{2}{*}{ Tota } \\
\hline & & Low & $\begin{array}{l}\text { Below } \\
\text { Average }\end{array}$ & Average & $\begin{array}{l}\text { Above } \\
\text { Average }\end{array}$ & High & \\
\hline \multirow{5}{*}{ 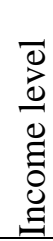 } & Below Rs. 200000 & 25 & 6 & 20 & 12 & 1 & 64 \\
\hline & Rs. $200000-400000$ & 11 & 9 & 29 & 11 & 3 & 63 \\
\hline & Rs. $400000-600000$ & 7 & 4 & 20 & 10 & 7 & 48 \\
\hline & Rs. $600000-800000$ & 1 & 2 & 7 & 6 & 8 & 24 \\
\hline & Rs. 800000 or Above & 0 & 1 & 7 & 4 & 9 & 21 \\
\hline & Total & 44 & 22 & 83 & 43 & 28 & 220 \\
\hline
\end{tabular}

Table 5: Chi-square test for Investors Income Level and Financial Risk Tolerance

\begin{tabular}{llll}
\hline & Value & Df & Asymp. Sig. (2-sided) \\
\hline Pearson Chi-Square & $57.431^{\text {a }}$ & 16 & 0.000 \\
\hline
\end{tabular}

Table 5 revealed the Pearson chi-square test results for investors income level and their financial risk tolerance and indicated calculated value that is 57.431 with significance value of 0.000 (less than 0.05 ). Where tabulated value of chi-square using $5 \%$ "level of significance "at 16 degree of freedom is 26.296. As our calculated value is higher than the tabulated value, so we reject our null hypothesis while accepting alternative hypothesis and concluded that investors income level has relationship with their levels of financial risk tolerance. Investors having different income levels shown different financial risk tolerance level during financial decision-making process.

Table 6: Relationship of Investors Age and their Financial Risk Tolerance Levels

\begin{tabular}{cccccccc}
\hline & \multicolumn{5}{c}{ Risk } & Total \\
\cline { 2 - 6 } & low & $\begin{array}{c}\text { Below } \\
\text { average }\end{array}$ & Average & $\begin{array}{c}\text { Above } \\
\text { average }\end{array}$ & High & \\
\hline Below 30 years & 27 & 13 & 40 & 20 & 4 & 104 \\
30-40 years & 14 & 6 & 32 & 17 & 13 & 82 \\
\& $40-50$ years & 3 & 2 & 7 & 4 & 7 & 23 \\
50-60 years & 0 & 1 & 3 & 2 & 4 & 10 \\
60 and above 60 & 0 & 0 & 1 & 0 & 0 & 1 \\
\hline Total & 44 & 22 & 83 & 43 & 28 & 220 \\
\hline
\end{tabular}

Table 6 revealed investors with different age group, shown the dissimilar behaviour toward financial risk. Investors having age less than 30 years mostly shown low risk

Sukkur IBA Journal of Management and Business - SIJMB | Volume 6 No. 1 January - June 2019 @ Sukkur IBA University 
tolerance, while investors from age group of 30 to 40 years shown average level of risk tolerance, and investors having age group of 50 to 60 mostly shown higher level of risk tolerance.

Table 7: Chi-square test for Investors Age and Financial Risk Tolerance Levels

\begin{tabular}{llll}
\hline & Value & Df & Asymp. Sig. (2-sided) \\
\hline Pearson Chi-Square & $26.925^{\text {a }}$ & 16 & .042 \\
\hline
\end{tabular}

Table 07 revealed the Pearson chi-square test results for investors age and their financial risk tolerance and indicated calculated value that is 26.925 with significance value of .042 (less than 0.05). Where value of chi-square using " $5 \%$ level of significance" at 16 degree of freedom in table is 26.296. As our calculated value is higher than the tabulated value, so we reject our null hypothesis while accepting alternative hypothesis and concluded that investors age has relationship with their level of financial risk tolerance. Investors having different age groups, shown different risk tolerance levels during financial decision-making process.

Table 8: The Relationship of Investors Marital Status and Financial Risk Tolerance Levels

\begin{tabular}{|c|c|c|c|c|c|c|c|}
\hline & & Risk & & & & & Total \\
\hline & & low & $\begin{array}{l}\text { Below } \\
\text { average }\end{array}$ & Average & $\begin{array}{l}\text { Above } \\
\text { average }\end{array}$ & High & \\
\hline & Single & 25 & 10 & 33 & 18 & 5 & 91 \\
\hline.$\stackrel{5}{=} \mathscr{E}$ & Married & 19 & 12 & 50 & 24 & 23 & 128 \\
\hline$\sum^{\frac{\pi}{2}} \frac{\pi}{\omega}$ & Divorced & 0 & 0 & 0 & 1 & 0 & 1 \\
\hline Total & & 44 & 22 & 83 & 43 & 28 & 220 \\
\hline
\end{tabular}

Table 08 revealed that investors either they are married or unmarried shown the similar trend toward financial risk while making the financial decision-making process.

Table 9: Chi-square Test for Investors Marital Status and Risk Tolerance

\begin{tabular}{llll}
\hline & Value & Df & Asymp. Sig. (2-sided) \\
\hline Pearson Chi-Square & $15.157^{\text {a }}$ & 8 & 0.056 \\
\hline
\end{tabular}

Sukkur IBA Journal of Management and Business - SIJMB | Volume 6 No. 1 January - June 2019 @ Sukkur IBA University 
Table 09 revealed the Pearson chi-square test results for investors age and their financial risk tolerance levels and indicated calculated value that is 15.157 with significance value of 0.056 . Where value of chi-square using " $5 \%$ level of significance" at 8 degree of freedom in table is 15.507 . As our calculated value is less than the tabulated value, so we accept our null hypothesis and concluded that investors marital status has no relationship with their levels of financial risk tolerance. Investors either they are married or unmarried shown the similar levels of risk tolerance.

Table 10: The Relationship of Financial Knowledge and Financial Risk Tolerance

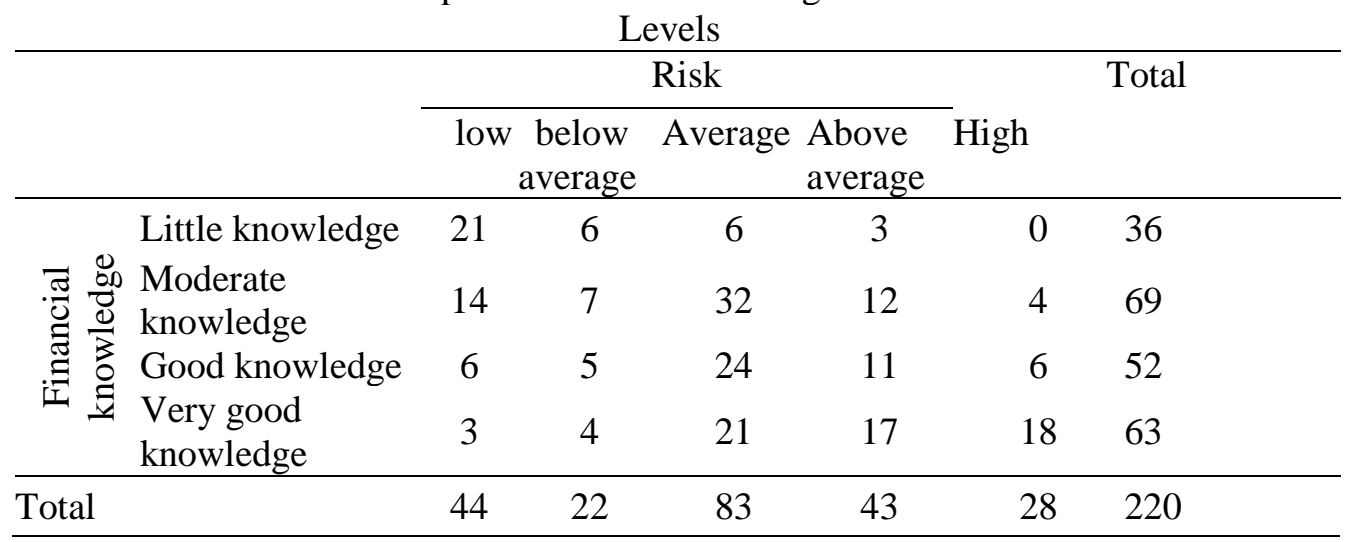

Table 10 revealed that investors with different financial knowledge shown the dissimilar trend while making the financial decision-making process. Respondents with fewer financial knowledge tolerate low risk in making financial decisions while investors with higher level of financial knowledge tolerate high level of risk.

Table 11: Chi-Square Test for Investors Financial Knowledge and Risk Tolerance

\begin{tabular}{llll}
\hline & Value & Df & Asymp. Sig. (2-sided) \\
\hline Pearson Chi-Square & $68.981^{\mathrm{a}}$ & 12 & 0.000 \\
\hline
\end{tabular}

Table 11 revealed the Pearson chi-square test results for investors financial knowledge and their financial risk tolerance and indicated calculated value that is 68.981 with significance value of 0.000 (less than 0.05 ). Where tabulated value of chi-square using $5 \%$ level of significance at 12 degree of freedom is 21.026 . As our calculated value is higher than the tabulated value, so we reject our null hypothesis while accepting alternative hypothesis and concluded that investors financial knowledge has relationship with their levels of financial risk tolerance. Investors having different levels of financial knowledge shown different levels of risk tolerance during financial decision-making process.

Sukkur IBA Journal of Management and Business - SIJMB | Volume 6 No. 1 January - June 2019 @ Sukkur IBA University 
Table 12: Relationship of Investors Family Size and Financial Risk Tolerance Levels

\begin{tabular}{|c|c|c|c|c|c|c|c|}
\hline & \multicolumn{5}{|c|}{ Risk } & \multirow[t]{2}{*}{ Total } \\
\hline & & low & $\begin{array}{c}\text { below } \\
\text { average }\end{array}$ & Average & $\begin{array}{l}\text { Above } \\
\text { average }\end{array}$ & High & \\
\hline \multirow{4}{*}{ 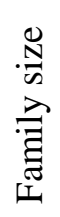 } & 2 members & 5 & 4 & 1 & 2 & 1 & 13 \\
\hline & 3-5 members & 30 & 13 & 60 & 25 & 14 & 142 \\
\hline & 6-8 members & 8 & 5 & 20 & 16 & 12 & 61 \\
\hline & $\begin{array}{l}9 \text { or more } \\
\text { members }\end{array}$ & 1 & 0 & 2 & 0 & 1 & 4 \\
\hline
\end{tabular}

Table 12 revealed that investors with different family size shown the dissimilar trend while making the financial decision-making process. Respondents with fewer family members tolerate low risk in making financial decisions while investors with 3 to 5 family members and more risk taker. Investors having more than 5 family members are average risk takers

Table 13: Chi-Square Test for Investors Family Size and Risk Tolerance

\begin{tabular}{llll}
\hline & Value & Df & Asymp. Sig. (2-sided) \\
\hline Pearson Chi-Square & $21.069 \mathrm{a}$ & 12 & .049 \\
\hline
\end{tabular}

Table 13 revealed the Pearson chi-square test results for investors family size and their levels of financial risk tolerance and indicated calculated value that is 21.069 with significance value of .049. Where tabulated value of chi-square using " $5 \%$ level of significance" at 12 degree of freedom is 21.026 . As our calculated value is higher than the tabulated value, so we reject our null hypothesis while accepting alternative hypothesis and concluded that investors family size has relationship with their levels of financial risk tolerance. Investors having different family size shown different levels of financial risk tolerance during financial decision-making process.

Table 14: Relationship of Investors Qualification and their Financial Risk Tolerance

\begin{tabular}{llcccccc}
\multicolumn{7}{c}{ Levels } \\
\hline & & \multicolumn{5}{c}{ Risk } & Total \\
\cline { 3 - 7 } & & low & $\begin{array}{l}\text { Below } \\
\text { average }\end{array}$ & Average & $\begin{array}{l}\text { Above } \\
\text { average }\end{array}$ & High & \\
\hline \multirow{3}{*}{ Qualification } & Below graduate & 19 & 8 & 13 & 3 & 3 & 46 \\
& Graduate & 22 & 10 & 53 & 29 & 5 & 119 \\
& Post graduate & 3 & 4 & 17 & 11 & 20 & 55 \\
\hline Total & & 44 & 22 & 83 & 43 & 28 & 220 \\
\hline
\end{tabular}

Sukkur IBA Journal of Management and Business - SIJMB | Volume 6 No. 1 January - June 2019 @ Sukkur IBA University 
Table 14 revealed that investors with different education level shown the dissimilar trend while making the financial decision-making process. Respondents with less qualification tolerate low risk in making financial decisions, while investors with high qualification tolerate high level of risk.

Table 15: Chi-Square Test for Investors Qualification and Risk Tolerance

\begin{tabular}{llll}
\hline & Value & Df & Asymp. Sig. (2-sided) \\
\hline Pearson Chi-Square & $60.598^{\mathrm{a}}$ & 8 & .000 \\
\hline
\end{tabular}

Table 15 revealed the Pearson chi-square test results for investors academic qualification and their levels of financial risk tolerance and indicated calculated value that is 60.598 with significance value of 0.000 (less than 0.05 ). Where value of chisquare using $5 \%$ level of significance" at 8 degree of freedom in table is 15.507 . As our calculated value is higher than the tabulated value, so we reject our null hypothesis and concluded that investor qualification level has relationship with their levels of financial risk tolerance. Investors having different levels of academic qualifications, shown different levels of risk tolerance.

Table 16: Relationship of Investors Occupation and their Risk Tolerance Levels

\begin{tabular}{|c|c|c|c|c|c|c|c|}
\hline & \multicolumn{5}{|c|}{ Risk } & \multirow[t]{2}{*}{ Total } \\
\hline & & Low & $\begin{array}{l}\text { Below } \\
\text { Average }\end{array}$ & Average & $\begin{array}{l}\text { Above } \\
\text { Average }\end{array}$ & High & \\
\hline \multirow{5}{*}{ Occupation } & Service & 19 & 10 & 50 & 24 & 19 & 122 \\
\hline & Professional & 11 & 3 & 6 & 7 & 0 & 27 \\
\hline & Student & 8 & 5 & 12 & 10 & 2 & 37 \\
\hline & Business & 3 & 3 & 11 & 2 & 7 & 26 \\
\hline & Others & 3 & 1 & 4 & 0 & 0 & 8 \\
\hline Total & & 44 & 22 & 83 & 43 & 28 & 220 \\
\hline
\end{tabular}

Table 16 revealed that investors with different occupations shown the dissimilar trend while making the financial decision-making process. Respondents doing service in any organization tolerate higher risk in making financial decisions, while investors, which are doing business, tolerate low level of risk.

Table 17: Chi-Square test for Investors Occupation and Risk Tolerance

\begin{tabular}{llll}
\hline & Value & Df & Asymp. Sig. (2-sided) \\
\hline Pearson Chi-Square & $28.970^{\mathrm{a}}$ & 16 & 0.024 \\
\hline \multicolumn{3}{l}{ Sukkur IBA Journal of Management and Business - SIJMB $\begin{array}{c}\text { Volume } 6 \\
100\end{array}$}
\end{tabular}


Table 17 revealed the Pearson chi-square test results for investors occupation and their levels of financial risk tolerance and indicated calculated value that is 28.970 with significance value of 0.024 (less than 0.05 ). Where value of chi-square using " $5 \%$ level of significance" at 16 degree of freedom is 26.296 . As our calculated value is higher than the tabulated value, so we reject our null hypothesis while accepting alternative hypothesis and concluded that investors occupation has relationship with their levels of financial risk tolerance.

Table 18: Relationship of Investors Personality Type and Their Risk Levels

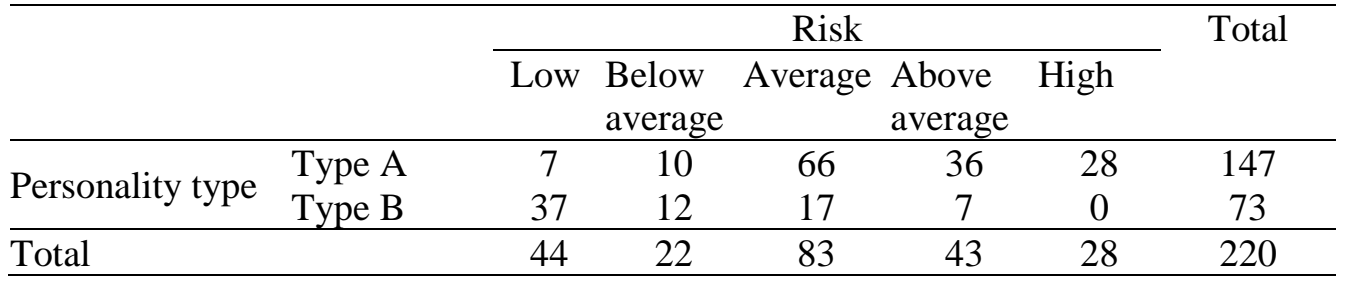

Table 18 shown the investors personality type and their level of risk tolerance levels. From table 18 this is concluded respondents having type " $\mathrm{A}$ " personality tolerate high risk in making financial decisions, while investors with type "B" tolerate low level of risk.

Table 19: Chi-Square Test for Investors Personality Type and Risk Tolerance Levels

\begin{tabular}{llll}
\hline & Value & Df & Asymp. Sig. (2-sided) \\
\hline Pearson Chi-Square & $81.446^{\mathrm{a}}$ & 4 & 0.000 \\
\hline
\end{tabular}

Table 19 revealed the Pearson chi-square test results for investors personality type and their financial risk tolerance and indicated calculated value that is 81.446 with significance value of 0.000 (less than 0.05 ). Where-tabulated value of chi-square using $5 \%$ level of significance at 4 degree of freedom is 9.488. As our calculated value is higher than the tabulated value, so we reject our null hypothesis and concluded that investors personality type has relationship with their levels of financial risk tolerance.

\subsection{Discussion}

\subsubsection{Gender}

Present study showed how people of different demographic traits shown different attitude toward financial risk tolerance. Present study has rejected the slovic (1966) general belief about the society that male shown higher financial risk tolerance and women are conservative in making financial decisions. Present study shown Investors either they were male, or female shown similar risk tolerance levels during investment

Sukkur IBA Journal of Management and Business - SIJMB | Volume 6 No. 1 January - June 2019 @ Sukkur IBA University 
decisions. These outcomes confirm the results of (Blum, 1976; Schubert et al. 1999; Jain\& Mandot, 2012).

\subsubsection{Income Level}

Present study supports the former studies revealing investors having higher level of income tend to tolerate higher level of risk as judge against to the investors having less income (MacCrimmon \& Wehrung, 1986). These results also supported by (Schooley \&Worden, 1996; Parker \& Terry 2002; Jain \& Mandot, 2012).

\subsubsection{Age}

Generally, it is perceived that young investors tolerate high risk during financial decision-making process. Study shown Increase in age lower the investors ability of financial risk tolerance (Grable, 1997). Present study also finds significant relationship between investors age and financial risk tolerance. These outcomes also support the results of (Wang \&Hanna, 1997; Grable \& Lytton, 1999b).

\subsubsection{Marital Status}

Previous studies shown individual investor has less to loss by accepting the superior risk as compare to married individual who have tasks for themselves and for their family. (Barber \& Odean, 2001). Study revealed married female shown less risk tolerance attitude while single women and married men shown moderate risk tolerance attitude. Further, this study shown single man tolerates more risk (Hinz et al. 1997) Present study disagreed with these results and concluded that investors marital status has no relationship with their levels of financial risk tolerance.

\subsubsection{Financial Knowledge}

Previous studies revealed investors having high investment knowledge gain high returns (Shaikh \& Kalkundarikar, 2011). Another study disclosed that investment knowledge and investment ability tend the investors to select the hotter stock (TouraniRad \& Kirkby, 2005; Jain, \& Mandot, 2012). Present study also supports these results and concluded that investors financial knowledge has relationship with their level of financial risk tolerance. Investors having good financial knowledge, tolerate more financial risk as compare to investors having less financial knowledge.

\subsubsection{Occupation}

Generally, it is perceived that, people having their own businesses, profession and trade takes more financial risk as compare to people who work for other against fixed salary (MacCrimmon Wehrung, 1985). Another study disclosed that investors with higher ranked occupations tolerate more financial risk as compare to investors having low ranked professions (Roszkowski et al. 1993; Barnewall, 1988). Another study shown that private salaried individual shown high-risk craving as compare to individual having their own business (Chattopadhyay \&Dasgupta, 2015). Present study shown investors occupational status has relationship with their level of financial risk tolerance. Study

Sukkur IBA Journal of Management and Business - SIJMB | Volume 6 No. 1 January - June 2019 @ Sukkur IBA University 
shown investors doing service in an organization tolerate more risk as compare to the investors having their own business and profession.

\subsubsection{Formal School Education}

Generally, it is perceived that investors having no formal school education are less likely to hold stock as compare to investors having some formal education (Haliassos $\&$ Bertaut, 1995). Investors have higher level of formal education tending to invest their funds in higher risky investments (Masters, 1989; Racciardi, 2007). Present study also shown that investors formal education has relationship with their level of financial risk tolerance. Investors having higher level of education tolerate high risk, while investors having less financial knowledge are enduring less financial risk.

\subsubsection{Family Size}

Generally, it is perceived that investors having fewer dependents are tend to take more risk as compare to the investors having more dependents. Study finds that higher number of dependents lessen risk tolerance aptitude and upsurge risk aversion (Chaulk et al. 2003). Present study also finds the significance relationship between investors family size and their levels of risk tolerance. Study shown investors having three to five family members shown the average risk tolerance behaviour, investors having 6 to 8 family members also prefer the average risk level. While investors having family size above 8 are less risk taker.

\subsubsection{Personality Type}

Study concluded that investors with Type A personality tolerate more risk as compare to the investors having type B personality trait (Glazer, 1985; Thanki, 2015). Present study also exposed the relationship between investors personality type with their levels of financial risk tolerance. Results shown investors having type A personality are more financial risk taker as compare to the investors having type B personality.

\section{Conclusion}

Empirical results provide enough evidence to conclude that investor's demographic characteristics have a significant relationship with financial risk tolerance. Investor's income level, age, financial knowledge, academic qualification, family size, occupation and personality have significant relationship with financial risk tolerance. In addition, gender, marital status has no relationship with financial risk tolerance because male and female investors exhibited same behaviour toward financial risk tolerance

Future research can compare different factors with investor's level of financial risk tolerance such as investor's psychology, market conditions, culture, and family background. Investment managers and financial planners should consider the importance of each factor while ranking the investments. Further the investigation into investment behavior due to the levels of financial literacy among managers would be an addition to the body of knowledge.

Sukkur IBA Journal of Management and Business - SIJMB | Volume 6 No. 1 January - June 2019 @ Sukkur IBA University 


\section{References:}

Ajmi, J. (2008). Risk Tolerance of Individual Investors in an Emerging Markets. International Research Journal of Finance and Economics, 17, 15-26.

Anbar, A., \& Eker, M. (2010). An empirical investigation for determining of the relation between personal financial risk tolerance and demographic characteristic. Ege Academic Review 10 (2) 2010: 503-523

Barberis, N., \& Thaler, R. (2003). A survey of behavioral finance. Handbook of the Economics of Finance, 1,1053-1128.

Barber, B. M., \& Odean, T. (2001). Boys will be boys: Gender, overconfidence, and common stock investment. The quarterly journal of economics, 116(1), 261292

Barber, B. M., Odean, T., \& Zhu, N. (2009). Do retail trades move markets?. Review of Financial Studies, 22(1), 151-186.

Barnewell, M. M. (1988). Examining The Psychological Traits Of Passive And Active Affluent Investors. Journal of Financial Planning, 1(2).

Belsky, G., \& Gilovich, T. (1999). Why smart people make big money mistakes. New York, NY, Fireside.

Bajtelsmit, V. L., Bernasek, A., \& Jianakoplos, N. (1996). Gender effects in pension investment allocation decisions. Center for Pension and Retirement Research, $145-156$.

Bernheim, B. D., Skinner, J., \& Weinberg, S. (2001). What accounts for the variation in retirement wealth among US households?. American Economic Review, 832-857.

Bernheim, B. D., Garrett, D. M., \& Maki, D. M. (2001). Education and saving:: The long-term effects of high school financial curriculum mandates. Journal of public Economics, 80(3), 435-465.

Blum, S. H. (1976). Investment preferences and the desire for security: A comparison of men and women. The Journal of Psychology, 94(1), 87-91.

Carducci, B. J., \& Wong, A. S. (1998). Type A and risk taking in everyday money matters. Journal of Business and Psychology, 12(3), 355-359.

Chaulk, B., Johnson, P. J., \& Bulcroft, R. (2003). Effects of marriage and children on financial risk tolerance: A synthesis of family development and prospect theory. Journal of Family and Economic Issues, 24(3), 257-279.

Chattopadhyay, S., \& Dasgupta, R. (2015). Demographic and Socioeconomic Impact on Risk Attitudes of the Indian Investors-An Empirical Study. Asian Economic and Financial Review, 5(4), 601.

Costa, P. T., \& McCrae, R. R. (1992). Four ways five factors are basic. Personality and individual differences, 13(6), 653-665.

Friedman, M., \& Rosenman, R. H. (1959). Association of specific overt behavior pattern with blood and cardiovascular findings: blood cholesterol level, blood clotting time, incidence of arcus senilis, and clinical coronary artery disease. Journal of the American Medical Association, 169(12), 1286-1296.

Sukkur IBA Journal of Management and Business - SIJMB | Volume 6 No. 1 January - June 2019 @ Sukkur IBA University 
Frijns, B., Koellen, E., \& Lehnert, T. (2008). On the determinants of portfolio choice. Journal of Economic Behavior \& Organization, 66(2), 373-386.

Filbeck, G., Hatfield, P., \& Horvath, P. (2005). Risk aversion and personality type. The Journal of Behavioral Finance, 6(4), 170-180.

Geetha, S.N., Vimala, K. (2014), Perception of household individual investors towards selected financial investment avenues. Procedia Economics and Finance 11, 360-374.

Gervais, S., Heaton, J. B., \& Odean, T. (2002). The positive role of overconfidence and optimism in investment policy. Rodney 1 white center for financial researchworking papers.

Grable, J. E., \& Lytton, R. H. (1999). Assessing financial risk tolerance: Do demographic, socioeconomic, and attitudinal factors work. Family Relations and Human Development/Family Economics and Resource Management Biennial, 3, 80-88.

Graham, J. F., Stendardi Jr, E. J., Myers, J. K., \& Graham, M. J. (2002). Gender differences in investment strategies: an information processing perspective. International journal of bank marketing, 20(1), 17-26.

Gumede, V. (2009). Demographic determinants of financial risk tolerance: A South African perspective. Unpublished B. Com. Hon. Thesis. Pietermaritzburg: University of KwaZulu-Natal.

Hassan Al-Tamimi, H. A., \& Anood Bin Kalli, A. (2009). Financial literacy and investment decisions of UAE investors. The Journal of Risk Finance, 10(5), 500-516.

Hersch, J. (1996). Smoking, seat belts, and other risky consumer decisions: Differences by gender and race. Managerial and decision economics, 471-481.

Hinz, R. P., McCarthy, D. D., \& Turner, J. A. (1997). Are women conservative investors? Gender differences in participant-directed pension investments. Positioning pensions for the twenty-first century, 91, 103.

Howard, \& Glazer, (1985). Stress management for the executive. (P.244-245). New York Berkeley Books.

Jain, D., \& Mandot, N. (2012). Impact of demographic factors on investment decision of investors in Rajasthan. Researchers World, 3(2), 81.

Jianakoplos, N. A., \& Bernasek, A. (2006). Financial risk taking by age and birth cohort. Southern Economic Journal, 981-1001.

Kannadhasan, M. (2015). Retail investors' financial risk tolerance and their risk-taking behaviour: The role of demographics as differentiating and classifying factors. IIMB Management Review, 27(3), 175-184.

Kimball, M. S., Sahm, C. R., \& Shapiro, M. D. (2008). Imputing risk tolerance from survey responses. Journal of the American statistical Association, 103(483), 1028-1038.

Korniotis, G. M., \& Kumar, A. (2011). Do older investors make better investment decisions?. The Review of Economics and Statistics, 93(1), 244-265.

Sukkur IBA Journal of Management and Business - SIJMB | Volume 6 No. 1 January - June 2019 C Sukkur IBA University 
Kourtidis, D., Šević, Ž., \& Chatzoglou, P. (2011). Investors' trading activity: A behavioural perspective and empirical results. The Journal of SocioEconomics, 40(5), 548-557.

Lewellen, W. G., Lease, R. C., \& Schlarbaum, G. G. (1977). Patterns of investment strategy and behavior among individual investors. The Journal of Business, 50(3), 296-333.

Loewenstein, G. F., Weber, E. U., Hsee, C. K., \& Welch, N. (2001). Risk as feelings. Psychological bulletin, 127(2), 267.

Mayfield, C., Perdue, G., \& Wooten, K. (2008). Investment management and personality type. Financial Services Review, 17(3), 219.

MacCrimmon, K. R., \& Wehrung, D. A. (1986). Taking risks: The management of uncertainty Free Press. New York.

Mahmood, M. (2015). Impact of personality on risk tolerance and investment decisions: A study on potential investors of Kazakhstan. International Journal of Commerce and Management, 25(4), 370-384.

Mittal, M., \& Vyas, R. K. (2007). Demographics and investment choice among Indian investors. ICFAI Journal of Behavioural Finance, 4(2), 12-20.

Masters, R. (1989). Study Examines Investors Risk-Taking Propensities. Journal of Financial Planning, 2(3).

Mischel, W., Shoda, Y., Smith, R. E., \& Mischel, F. W. (2004). Introduction to personality. University of Phoenix: A John Wiley \& Sons, Ltd., Publication.

Mehta, S. K., \& Aggarwal, N. (2011). The effect of demographics on investment choice: An empirical study of investors in Jammu. Indian Journal of Finance, 5(10), 43-55.

Fama, E. F. (1970). Efficient capital markets: A review of theory and empirical work. The journal of Finance, 25(2), 383-417.

Odean, T. (1998). Are investors reluctant to realize their losses?. The Journal of finance, 53(5), 1775-1798.

Ritter, J. R. (2003). Behavioral finance. Pacific-Basin finance journal, 11(4), 429-437.

Rickman, B., Parker, C., \& Terry, R. (2002). Gender Based Differences in Asset Allocations: Evidence from Kansas Board of Regents Faculty. Journal of Financial and Economic Practice, 1(2).

Rajdev, A. (2013). The Effect of Demographic factors on Investment Choice of Investors: A Study on Investors of Bhopal. IRC's International Journal Of Multidisciplinary Research in Social \& Management Sciences, 1(3), 110-116.

Roszkowski, M. J., Snelbecker, G. E., \& Leimberg, S. R. (1993). Risk tolerance and risk aversion. The tools and techniques of financial planning, 4, 213-225.

Shaikh, A. R. H., \& Kalkundarikar, A. (2011). Analysis of retail investor's behaviour in Belgaum district, Karnataka state. International Journal for Management Research, 1(2), 22-39.

Schooley, D. K., \& Worden, D. D. (1996). Risk aversion measures: Comparing attitudes and asset allocation. Financial services review, 5(2), 87-99.

Sukkur IBA Journal of Management and Business - SIJMB | Volume 6 No. 1 January - June 2019 ๑ Sukkur IBA University 
Sharma, M., \& Vasakarla, V. (2013). An empirical study of gender differences in risk aversion and over confidence in investment decision making. International Journal of Application or Innovation in Engineering \& Management, 2(7), 497504.

Slovic, P. (1966). Risk-taking in children: Age and sex differences. Child Development, 169-176.

Snelbecker, G. E., Roszkowski, M. J., \& Cutler, N. E. (1990). Investors' risk tolerance and return aspirations, and financial advisors' interpretations: A conceptual model and exploratory data. Journal of Behavioral Economics, 19(4), 377-393.

Strydom, B., Christison, A., \& Gokul, A. (2009). Financial risk tolerance: A South African perspective. School of Economics \& Finance.

Sulaiman, E. K. (2012). An empirical analysis of financial risk tolerance and demographic features of individual investors. Procedia Economics and Finance, 2, 109-115.

Sung, J., \& Hanna, S. (1996). Factors related to risk tolerance. Journal of Financial Counseling and Planning, 7, 11.

Talangy, A (2004). The Interaction of Modern Finance Theory and Behavioral Finance. Journal of Financial Research, 17, 3-25.

Taylor, B. J., Dempster, M., \& Donnelly, M. (2007). Grading gems: Appraising the quality of research for social work and social care. British Journal of Social Work, 37(2), 335-354.

Thanki, H., \& Jadeja, A. (2014). Risk tolerance dependent on what? demographics or personality type: findings from an empirical Research. ZENITH International Journal of Business Economics \& Management Research, 4(12), 25-37.

Thoresen, C. E., \& Low, K. G. (1990). Women and the Type A behavior pattern: Review and commentary. Journal of social behavior and personality, 5(1), 117.

Tourani-Rad, A., \& Kirkby, S. (2005). Investigation of investors' overconfidence, familiarity and socialization. Accounting \& Finance, 45(2), 283-300.

Verma, M. (2008). Wealth management and behavioral finance: The effect of demographics and personality on investment choice among Indian investors. The ICFAI University Journal of Behavioural Finance, 5(4), 31-57.

Wallach, M. A., \& Kogan, N. (1961). Aspects of judgment and decision making: Interrelationships and changes with age. Behavioral science, 6(1), 23-36

Xiao, J. J. (1996). Effects of family income and life cycle stages on financial asset ownership. Journal of Financial Counseling and Planning, 7, 21.

Yao, R., Hanna, S. D., \& Lindamood, S. (2004). Changes in financial risk tolerance, 1983-2001.

Young, S., Gudjonsson, G. H., Carter, P., Terry, R., \& Morris, R. (2012). Simulation of risk-taking and it relationship with personality. Personality and Individ

Sukkur IBA Journal of Management and Business - SIJMB | Volume 6 No. 1 January - June 2019 @ Sukkur IBA University 